\title{
Retarding effect of grinding dust and its influence on the physical-mechanical and rheological properties of cementitious matrices
}

\section{Efeito retardador do pó de retifica e sua influência nas propriedades físico-mecânicas e reológicas das matrizes cimentícias}
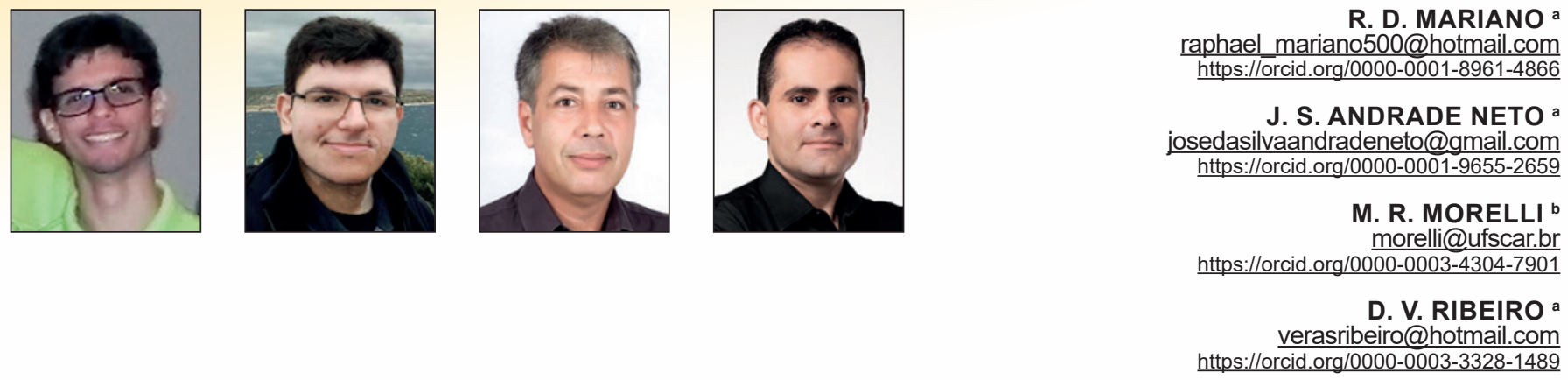

\begin{abstract}
The present study evaluated the feasibility of the use of grinding dust (GD), a waste generated in the clutch disc finishing process, as a retardant additive in cementitious matrices. For this, the waste was added in contents of $5 \%, 10 \%$ and $15 \%$, relative to the cement weight, and the setting time was determined by the Vicat method. In addition, the influence of this material on rheology (flow table, squeeze-flow and rotational rheometry) and on the physical-mechanical properties of the hardened matrices was analyzed. The results indicated an increase in setting time and a reduction in the fluidity of the mortars as a function of the addition of GD and the best results for the hardened state properties were verified for the cementitious matrices containing a $5 \%$ addition. Therefore, it was observed that GD is effective in retarding the setting time, presenting great potential for use in civil construction, without impairing its properties.
\end{abstract}

Keywords: waste, grinding dust, retarding admixture, rheology, physical-mechanical properties.

\section{Resumo}

O presente estudo avaliou a viabilidade da utilização do pó de retífica (PR), resíduo gerado na produção de revestimentos de discos de embreagem, como aditivo retardador em matrizes cimentícias. Para isso, o PR foi adicionado nos teores de $5 \%, 10 \%$ e $15 \%$, em relação à massa de cimento, e avaliou-se o efeito desta adição no tempo de pega, pelo método de Vicat. Além destes ensaios, foi analisada a influência deste material na reologia (flow table, squeeze-flow e reometria rotacional) e nas propriedades físico-mecânicas das matrizes endurecidas. Os resultados indicaram um retardo de pega crescente em função de um maior teor de PR adicionado e uma redução na fluidez das matrizes cimentícias, sendo que os melhores resultados para as propriedades no estado endurecido foram verificados para as matrizes cimentícias contendo $5 \%$ de adição. Assim, observou-se que o PR é eficaz no retardo da pega, apresentando grande potencial de utilização na construção civil, sem prejudicar as suas propriedades.

Palavras-chave: resíduo, pó de retífica, aditivo retardador, reologia, propriedades físico-mecânicas. 


\section{Introduction}

The use of industrial waste as additives to cement matrices or supplementary cementitious materials (SCM) has been thoroughly studied in the past years. In several countries, such wastes are being viewed from a new perspective, as important inputs in production and with aggregate economic value, being considered byproducts [1]. The development of uses for these wastes has also become a focus of the productive process.

Among the different wastes generated by the automotive industry is grinding dust (GD), a powdery material generated in the production of clutch discs, during the machining stage. The generation of this waste in Brazil by ZF Sachs do Brasil, the largest industry in the sector, is approximately 40 tonnes/month, according to data presented in Figure 1. The decrease in GD generated in recent years is probably associated with the economic recession in Brazil that has had a direct impact on the sale of automobiles and, consequently, the production of clutch discs.

The grinding dust of the clutch discs is the waste generated in the finishing process, carried out by sanding and drilling. The process of making clutch discs begins with the production of mixed fibers (composed of metallic fibers, polymer fibers and glass fiber) which are interlaced and immersed in a solution of rubber in a bath containing the other additives used for the final composition of the product [2]. The discs are then shaped from this rubberized pre-product and taken to a hot press tower. The product is perforated and rectified and the material generated in this process is collected by a suction system [2]. The process of production of clutch discs and generation of GD can be seen in Figure 2. Nowadays, grinding dust it is normally not re-used and/or recycled, being destined to incineration. This is not the most environmentally friendly practice of disposing of wastes due to the emission of pollutants and contamination of neighboring communities [3]. Studies that aim to develop alternatives for reuse and/or recycling of grinding dust are extremely necessary.

However, due to the highly hazardous nature of the waste and the small number of sites in the world that generate it, the amount of scientific work that deals with the reuse of grinding dust from clutch discs is scarce. RIBEIRO and MORELLI $[4,5]$ and RIBEIRO et al.

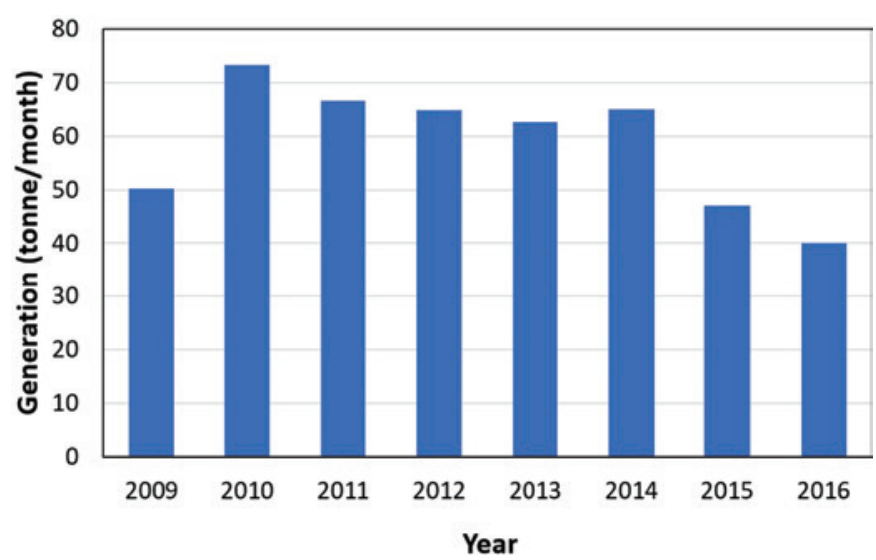

Figure 1

Average amount of Grinding Dust generated per month by ZF Sachs do Brasil in the recent years

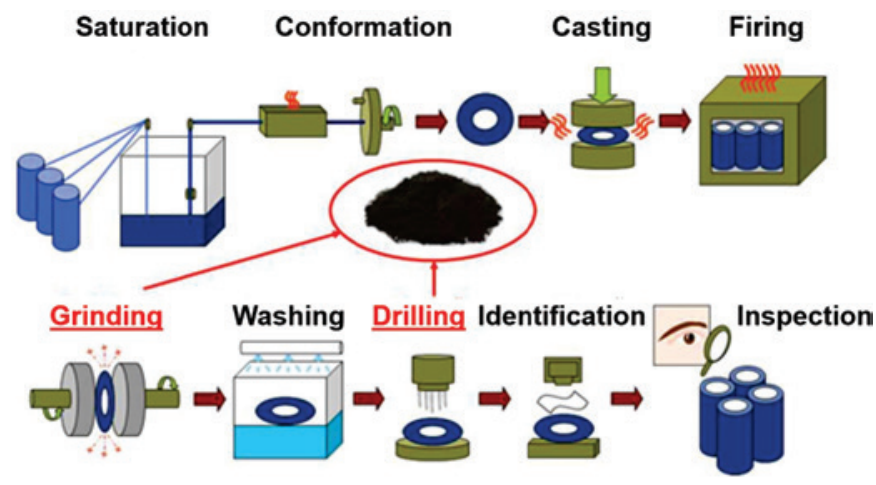

Figure 2

Schematic representation of the production process of clutch discs [2]

[6] evaluated the influence of the addition of this waste on the properties of magnesium phosphate cement matrices, such as setting time, mechanical strength and durability, but did not evaluate its effect when added to Portland cement matrices.

Alkaline matrices, such as Portland cement, are commonly used for waste conditioning due to the low cost, a long history of use and easily accessible technology used. Its high alkalinity, with $\mathrm{pH}$ around 12.5 , greatly reduces the solubility of various toxic or hazardous inorganic compounds and inhibits microbiological processes. In addition, as observed by RIBEIRO and MORELLI [5], grinding dust contains zinc oxide $(\mathrm{ZnO})$ and copper $(\mathrm{CuO})$ oxides, as well as phenolic resins, which are known to retard the cement hydration process [7 - 22].

Several studies [7 - 16] show that the presence of zinc and its compounds influence the hydration of cement with the formation of zinc hydroxide $\left[\mathrm{Zn}(\mathrm{OH})_{2}\right]$. During the hydration process, the high concentrations of $\mathrm{Ca}^{2+}$ and $\mathrm{OH}^{-}$in the pores causes $\mathrm{Zn}(\mathrm{OH})_{2}$ to react, according to equation (1), to form calcium hydroxy-zincate $\left[\mathrm{CaZn}{ }_{2}(\mathrm{OH})_{6} \cdot 2 \mathrm{H}_{2} \mathrm{O}\right]$.

$2 \mathrm{Zn}(\mathrm{OH})_{2}+2 \mathrm{OH}^{-}+\mathrm{Ca}^{2+}+2 \mathrm{H}_{2} \mathrm{O} \rightarrow \mathrm{CaZn}_{2}(\mathrm{OH})_{6} \cdot 2 \mathrm{H}_{2} \mathrm{O}$

Although some research has related the delay in the hydration process with the presence of zinc, with the formation of calcium hydroxy-zincate, there is no consensus regarding the agent or process responsible for the delay. For ARIGUIE and GRANDET [7] and LI et al. [10], the retarding effect of $\mathrm{ZnO}$ is attributed to the precipitation of zinc hydroxide on the grains of cement. While for YOUSUF et al. [11] and ASAVAPISIT et al. [12], the delay is related to the precipitation of hydroxy-zincate. For both theories, the delay is explained by the formation of a layer of low permeability and solubility around the anhydrous cement particles, which hinders the transport of ions and water, thus slowing down the hydration process.

According to STEPHAN et al. [13], TREZZA [14] and WEEKS et al. [15], the delay in the setting time is caused by the calcium hydroxyzincate, which consumes calcium and hydroxyl ion in the reaction, preventing them from precipitating and forming $\mathrm{C}-\mathrm{S}-\mathrm{H}$ and portlandite. Thus, until the reaction is complete, the $\mathrm{Ca}^{2+}$ and $\mathrm{OH}^{-}$concentrations are kept low and there is no supersaturation, which is required for the precipitation of $\mathrm{C}-\mathrm{S}-\mathrm{H}$ and portlandite. 
Copper oxide $(\mathrm{CuO})$ and phenolic resins present in the grinding dust are also responsible for retarding the cement hydration process $[17-19,21,22]$. Similar to $\mathrm{ZnO}$, the retarding effect of $\mathrm{CuO}$ is also not completely understood and, according to KAKALI et al. [20], is due to the formation of a layer $\mathrm{Cu}(\mathrm{OH})_{2}$ on the surface of the cement particles, which hinders the diffusion of ions and the passage of water. In relation to the phenolic resins, at the initial moments of hydration these are adsorbed on the surface of the cement particles, reducing the passage of water and the diffusion of calcium ions [21, 221].

Due to its physical, chemical and mineralogical properties, grinding dust therefore has great potential as a retarder additive to the cementitious matrix, adding value to this waste. However, it is of fundamental importance to observe if the presence of GD, which has high fineness and it is rich in zinc, copper, glass fiber and phenolic resins, does not negatively influence the rheological and physicalmechanical properties of the cementitious matrices.

It is expected that the addition of the grinding dust will have several effects on the cement matrix. Its very fine particles have the potential to fill voids between the hydration products (filler effect), thus reducing porosity and, thereby improving the mechanical properties. The mechanical properties can also be influenced positively by the presence of fibre glass in the GD, which promotes an increase in the tensile strength. On the other hand, the glass fiber hinders the workability of the mixture $[23,24]$.

The focus of the present paper is to evaluate the potential of use of grinding dust as a retarder additive of setting time in cementitious matrices. Additionally, the effect of the addition of this waste
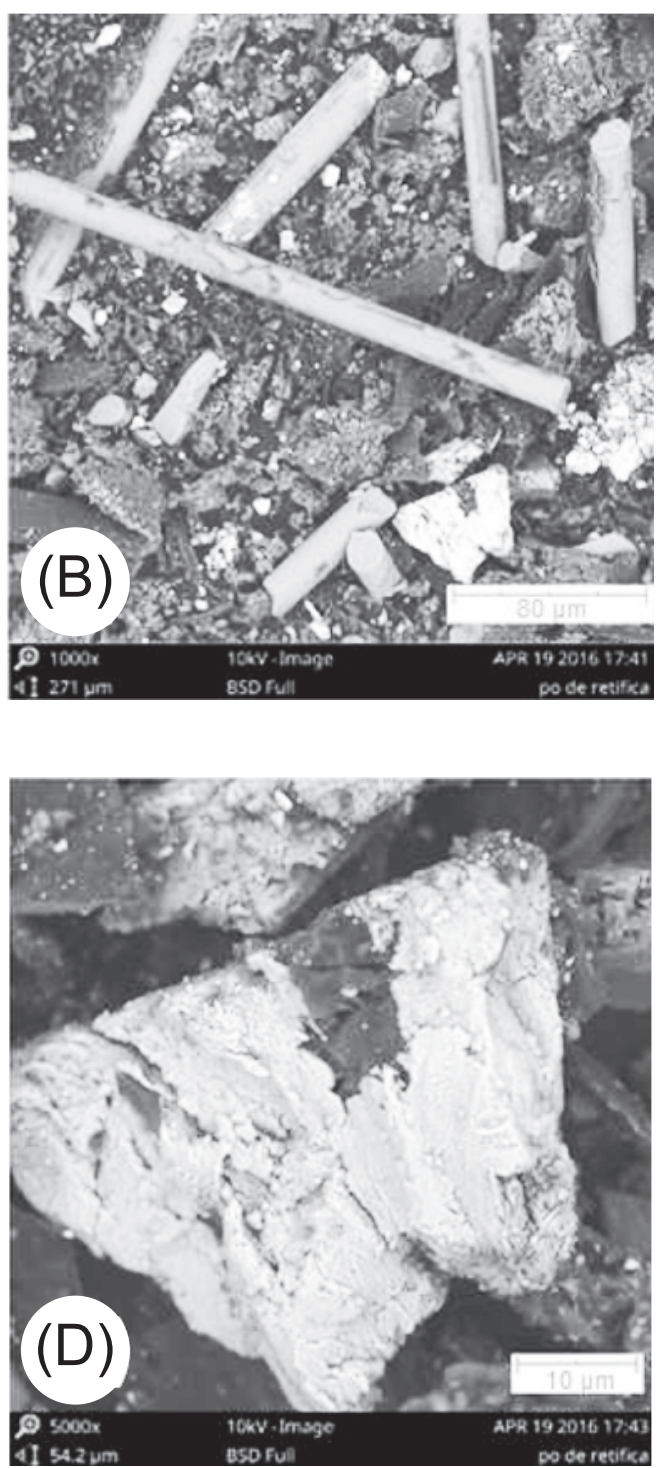

\section{Figure 3}
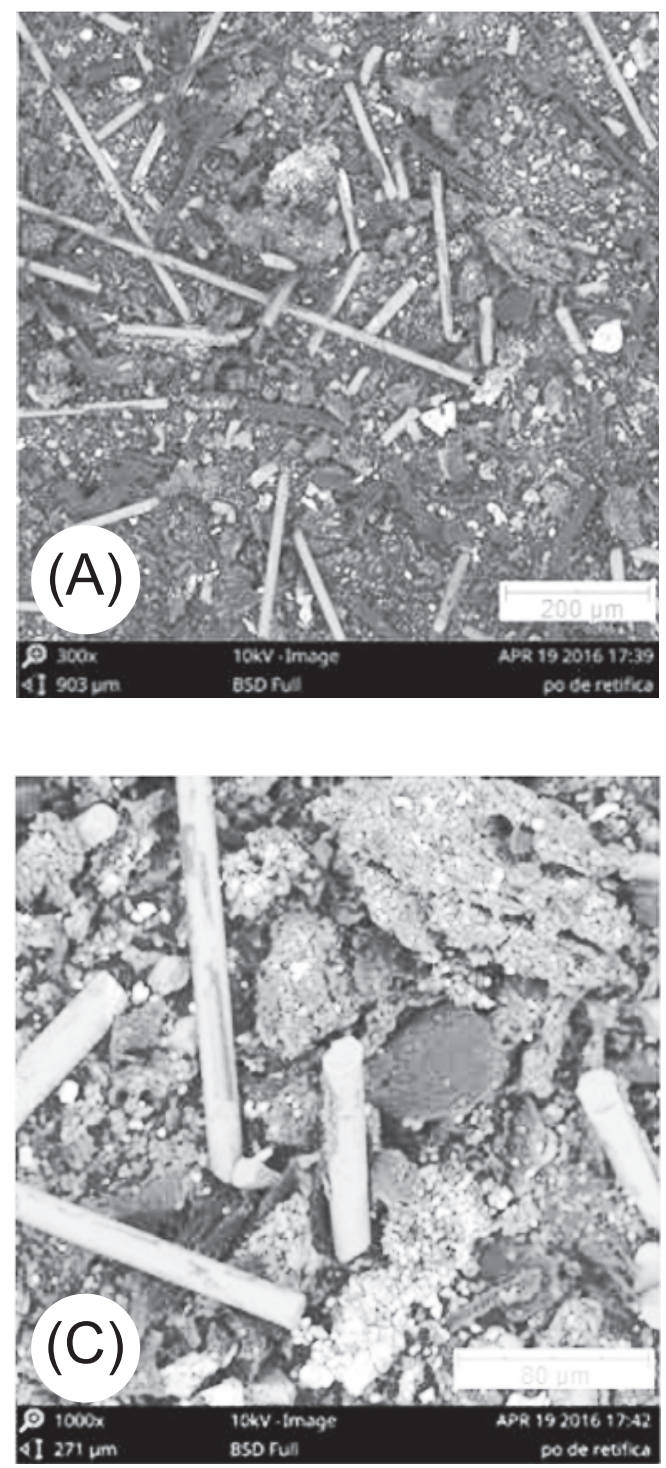

Micrographs of GD obtained by scanning electron microscopy (SEM), showing:

(A) general view of the morphology of the particles present in the GD; (B) approximation of the particle overview; (C) stick-shaped particle; (D) irregular shaped particle 


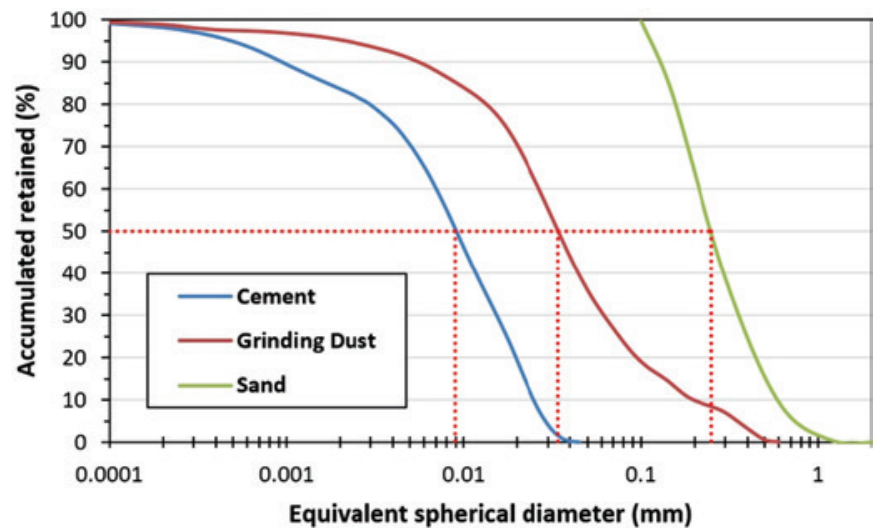

Figure 4

Particle size distribution of GD, cement and sand

on the rheology and on the physical-mechanical properties of the cementitious matrices was analyzed, so as to investigate the technical feasibility of this addition.

\section{Materials and methods}

\subsection{Materials}

Portland cement CP V ARI, sand commercialized in the city of Salvador-BA, Brazil, water from the public supply network (Embasa Empresa Baiana de Água e Saneamento AS) and the grinding dust generated by ZF Sachs do Brasil Ltda., located in São Bernardo do Campo, São Paulo, Brazil, were used to produce the cementitious matrices.

The Portland cement used in this paper has a specific gravity of $3.13 \mathrm{~kg} / \mathrm{dm}^{3}$ and a Blaine specific surface area of $0.4255 \mathrm{~m}^{2} / \mathrm{g}$. The sand used has a bulk density of $1.46 \mathrm{~kg} / \mathrm{dm}^{3}$, specific gravity of 2.67 $\mathrm{kg} / \mathrm{dm}^{3}$, fineness modulus of 1.32 (the sand classified as very fine), maximum particle size of $1.18 \mathrm{~mm}$ and $2.20 \%$ of powdery material. The grinding dust used has a specific gravity of $2.10 \mathrm{~kg} / \mathrm{dm}^{3}$ and a Blaine specific surface area of $0.2954 \mathrm{~m}^{2} / \mathrm{g}$. Grinding dust is a very complex material with particles of different shapes and sizes due to their several constituents (metal fibers, polymer fibers and glass fiber), as can be seen in the micrographs shown in Figure 3, which were obtained using a scanning electron microscope (SEM) of Phenom, model Pro-X.

Figures $3 c$ and $3 d$ show this heterogeneity of shapes and sizes. For example, regular shaped particles (Figure 3c) such as rods of different sizes, and other more irregular such as shown in Figure $3 \mathrm{~d}$ can be seen. The cross section of the rods present in the material are solid, according to the micrograph presented in Figure 3c. This is important because if they were leaked more water would be required to prepare the mixtures with GD [2].

Comparing the particle size distributions of the grinding dust and cement (obtained in a CILAS 1180 laser granulometer) with the sand particle size distribution (obtained by mechanical sieving), we obtain the representation presented in Figure 4. The diameters $\left(D_{50}\right)$ obtained for cement, grinding dust and sand were $0.009 \mathrm{~mm}$, $0.028 \mathrm{~mm}$ and $0.25 \mathrm{~mm}$, respectively. In relation to $\mathrm{GD}$, the distribution is quite broad, varying from $0.04 \mu \mathrm{m}$ to $600 \mu \mathrm{m}$. However,
Table 1

Chemical composition of the grinding dust, in oxides, determined by XRD

\begin{tabular}{cccc}
\hline Constituent & Content (\%) & Constituent & Content (\%) \\
\hline $\mathrm{SO}_{3}$ & 30.40 & $\mathrm{MgO}$ & 1.79 \\
$\mathrm{CuO}$ & 20.20 & $\mathrm{Fe}_{2} \mathrm{O}_{3}$ & 0.58 \\
$\mathrm{SiO}$ & 16.90 & $\mathrm{~K}_{2} \mathrm{O}$ & 0.32 \\
$\mathrm{CaO}$ & 13.60 & $\mathrm{TiO}_{2}$ & 0.19 \\
$\mathrm{ZnO}$ & 4.98 & $\mathrm{CsO}_{2}$ & 0.19 \\
$\mathrm{Al}_{2} \mathrm{O}_{3}$ & 4.20 & $\mathrm{P}_{2} \mathrm{O}_{5}$ & 0.19 \\
$\mathrm{BaO}$ & 4.16 & $\mathrm{~V}_{2} \mathrm{O}_{5}$ & 0.10 \\
$\mathrm{MnO}$ & 2.11 & $\mathrm{LOI}^{*}$ & 37.70 \\
\hline "Loss on ignition. & & &
\end{tabular}

great care must be taken in analyzing this result because the particle diameters obtained by the laser granulometer are given by the circumferences that circumscribe them. Thus, elongated particles and stick-shaped particles present in GD (see Figure 3) tend to increase the value of the average particle diameter of the waste, thus impairing the analysis of this result.

Table 1 shows the chemical composition of the grinding dust, obtained by X-ray fluorescence (XRF) technique using a Bruker equipment, model S2 Ranger. Among the constituents of the grinding dust, there is copper oxide ( $\mathrm{CuO})$, which is recognized as a retarder of cement hydration [17 - 19]. In addition, there is the presence of zinc oxide $(\mathrm{ZnO})$, which even in small quantities is responsible for retarding the setting time of the cementitious matrix very effectively [7-16]. Finally, the presence of sulfur in the GD composition can be observed, which may generate degradation of the cementitious matrix if it is not chemically combined.

Figure 5 shows the X-ray scan of the grinding dust obtained by a Bruker D2 Phaser diffractometer with copper tube, scanning from $5^{\circ}$ to $70^{\circ}(2 \theta)$ and increase of $0.001^{\circ} / \mathrm{s}$, with $10 \mathrm{~mA}$ current and $30 \mathrm{kV}$ voltage. Using the DIFFRAC plus-EVA software, with a database centered on the COD system (Crystallography Open Database), it was possible to identify the phases present in the material as well as the amorphous content. It was observed that

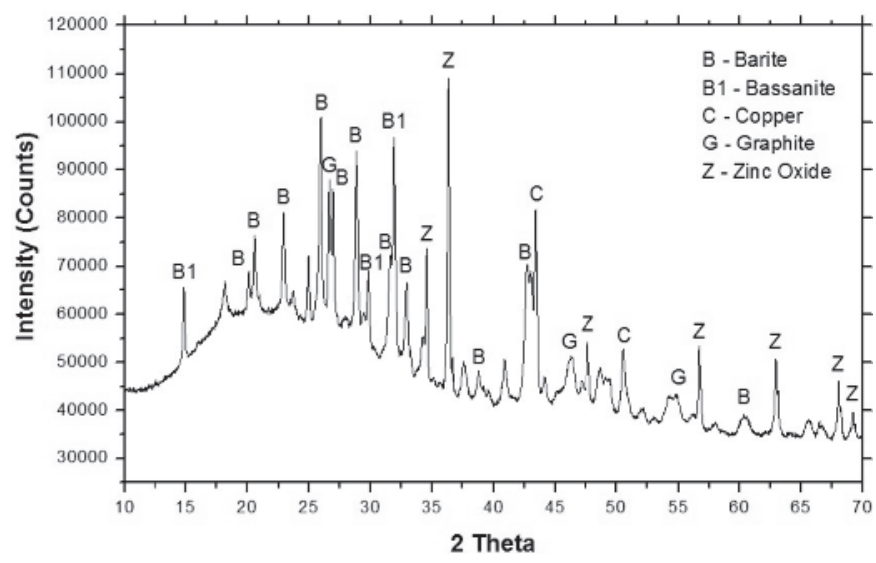

Figure 5

X-ray scan of the GD (barite: $\mathrm{BaSO}_{4^{\prime}}$; bassanite: $\mathrm{CaSO}_{4} \cdot 1 / 2 \mathrm{H}_{2} \mathrm{O}$ ) 
its degree of amorphization is $33.7 \%$, probably associated with the presence of glass fiber and phenolic resins in the GD composition. It was also possible to observe the presence of barite $\left(\mathrm{BaSO}_{4}\right)$ and basanite $\left(\mathrm{CaSO}_{4} \cdot 1 / 2 \mathrm{H}_{2} \mathrm{O}\right)$, evidencing the presence of sulfates in GD.

Environmental characterization (leaching/solubilization) tests with grinding dust were also performed according to NBR 10005:2004 [25] and 10006:2004 [26]. The results are presented in Table 2, as well as the limits established in NBR 10004:2004 [27].

No elements in higher concentrations than those allowed in the leached extract were detected, which classifies this material as non-hazardous (Class II). On the other hand, in the solubilized extract, higher concentrations than the limits allowed for aluminum, cadmium, lead, manganese, iron and total phenols were detected, which classifies this material as a non-hazardous non-inert waste (Class II-A), unlike the classification found by RIBEIRO and MORELLI [5]. This is due to the change in the productive process by the generating industry, which was influenced by more rigorous and restrictive environmental regulation and inspection. In particular, values for solubilization of cadmium and total phenols were much higher than those permitted by the standard.

\subsection{Methods}

\subsubsection{Cementitious matrices mix design}

For the evaluation of the influence of grinding dust on the rheology and on the physical-mechanical properties of the cementitious matrix, a mix design of $1.0: 2.6: 0.59$ (cement : sand: water) was used, with the addition of three different contents $(5 \%, 10 \%$ and $15 \%$, relative to the cement weight), as well as a reference mixture (without the addition of the waste). No limit was specified for the consistency of the cementitious matrices.

\subsubsection{Rheological characterization}

The flow indexes (flow table) of the cementitious matrices with the addition of grinding dust were determined by the method prescribed by NBR 13276:2005 [28]. For this purpose, a Contenco automatic consistency table, model I-3019-B was used.

The squeeze-flow tests were performed following the recommendations of NBR 15839:2010 [29], using for this a INSTRON universal test machine, with displacement control and load cell

\section{Table 2}

Results of the solubilization and leaching tests for the grinding dust, according to NBR 10004:2004, 10005:2004 and 10006:2004

\begin{tabular}{|c|c|c|c|c|}
\hline \multirow[b]{2}{*}{ Parameters } & \multicolumn{2}{|c|}{ Solubilization } & \multicolumn{2}{|c|}{ Leaching } \\
\hline & $\begin{array}{l}\text { Result } \\
\mathrm{mg} / \mathrm{L}\end{array}$ & $\begin{array}{l}\text { MVA* } \\
\text { mg/L }\end{array}$ & $\begin{array}{l}\text { Result } \\
\mathrm{mg} / \mathrm{L}\end{array}$ & $\begin{array}{l}\text { MVA* } \\
\text { mg/L }\end{array}$ \\
\hline Aluminum & 0.63 & 0.2 & $x$ & $\#$ \\
\hline Arsenic & $\mathrm{Nd}$ & 0.01 & $\mathrm{Nd}$ & 1.0 \\
\hline Barium & 0.6 & 0.7 & 0.9 & 70.0 \\
\hline Cadmium & 0.06 & 0.005 & $\mathrm{Nd}$ & 0.5 \\
\hline Lead & 0.04 & 0.01 & 0.03 & 1.0 \\
\hline Copper & 1.5 & 2.0 & $x$ & $\#$ \\
\hline Total chromium & 0.03 & 0.05 & 0.06 & 5.0 \\
\hline Manganese & 0.63 & 0.10 & $\#$ & $\#$ \\
\hline Mercury & $\mathrm{Nd}$ & 0.001 & $\mathrm{Nd}$ & 0.1 \\
\hline Selenium & $\mathrm{Nd}$ & 0.01 & $\mathrm{Nd}$ & 1.0 \\
\hline Sodium & 63.0 & 200.0 & $x$ & $\#$ \\
\hline Zinc & 4.65 & 5.0 & $x$ & $\#$ \\
\hline Iron & 0.59 & 0.3 & $x$ & $\#$ \\
\hline Cyanides & $\mathrm{Nd}$ & 0.07 & $x$ & \# \\
\hline Chlorides & 34.0 & 250.0 & $x$ & $\#$ \\
\hline Total phenols & 3.59 & 0.01 & $x$ & $\#$ \\
\hline Nitrates & 6.3 & 10.0 & $x$ & $\#$ \\
\hline Fluorides & 1.36 & 1.5 & 1.36 & 150.0 \\
\hline Sulfates & 114.77 & 250.0 & $x$ & \# \\
\hline Surfactants & $\mathrm{Nd}$ & 0.5 & $x$ & \# \\
\hline Benzene & $x$ & $\#$ & 0.2 & 0.5 \\
\hline Chlorobenzene & $x$ & $\#$ & 1.3 & 100.0 \\
\hline Chloroform & $x$ & $\#$ & 0.3 & 6.0 \\
\hline Carbon tetrachloride & $x$ & $\#$ & 0.06 & 0.02 \\
\hline Tetrachlorethylene & $x$ & \# & 0.03 & 4.0 \\
\hline Trichlorethylene & $x$ & $\#$ & 0.04 & 7.0 \\
\hline
\end{tabular}

\# - Absence of a limit established by the NBR 10004:2004 standard; X - Not required by the NBR 10004:2004 standard; Nd - Not detected.

*MVA - Maximum value allowed by the NBR 10004:2004 standard. 


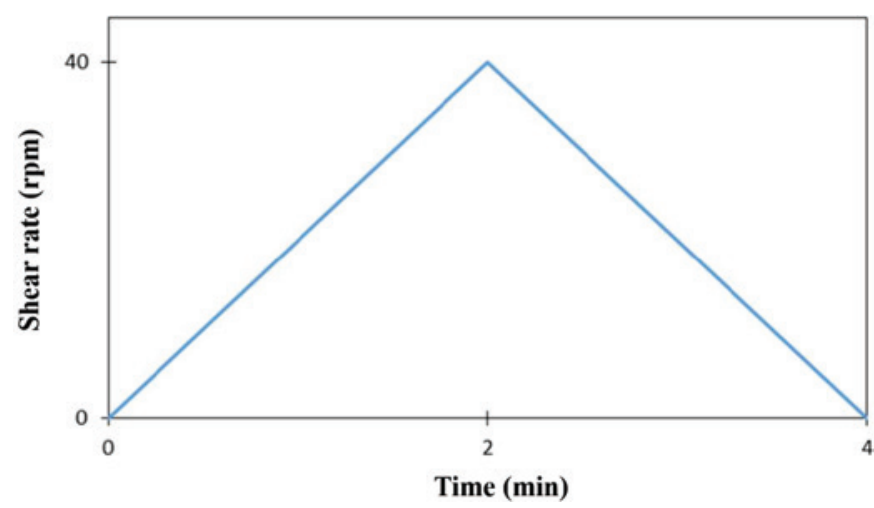

Figure 6

Test setup adopted for the flow test on the rheometer

of $5 \mathrm{kN}$, after 15 minutes of mixing, using a displacement speed of $0.1 \mathrm{~mm} / \mathrm{s}$.

The rheological properties of the pastes with different additions of grinding dust were obtained using a Rheotest Medingen $\mathrm{GmbH}$ RN 4.1, rotational type rheometer. In this test, a procedure adapted from Betioli et al. [30], shown in Figure 6, was used. The rheological parameters were obtained by applying the Herschel-Bulkey model in the curve obtained in the deceleration of the rheometer palettes, according to studies by VIKAN and JACOBSEN [31], LIU et al. [32] and ANDRADE NETO and SILVA [33].

\subsubsection{Influence of GD on the physical-mechanical properties of cementitious matrices}

For the characterization of the cementitious matrix in the hardened state, tensile and compressive strength tests according to NBR 13279:2005 [34] were carried out. For tensile strength tests, 4 (four) specimens measuring $4 \mathrm{~cm} \times 4 \mathrm{~cm} \times 16 \mathrm{~cm}$ were used. After the rupture of these specimens, five of the eight halves obtained were subjected to axial compression. The other three halves were subjected to the apparent porosity and density tests using a technique based on the Archimedes principle. The mechanical strength test were carried out using a servo-controlled press of Contenco, model HD-120T, with a capacity of $120 \mathrm{tf}$.

Further tests were carried out to determine the coefficient of water absorption by capillarity (absorptivity) and the height of capillary ascension according to ABNT NBR 9779:2012 [35]. For the capillary water absorption test, three cylindrical specimens measuring $5 \mathrm{~cm}$ in diameter and $10 \mathrm{~cm}$ in height were used. At the end of the test, the specimens were diametrically ruptured and capillary ascending heights in each specimen were measured.

\subsubsection{Analysis of the setting time of the cementitious matrix}

The influence of GD on the setting time was measured using the Vicat method, according to ABNT NBR NM 65:2003 [36]. The tests were done in triplicate to determine the setting time, and the average of these results was presented. The equipment used for this test was the Solatest automatic Vicat apparatus.

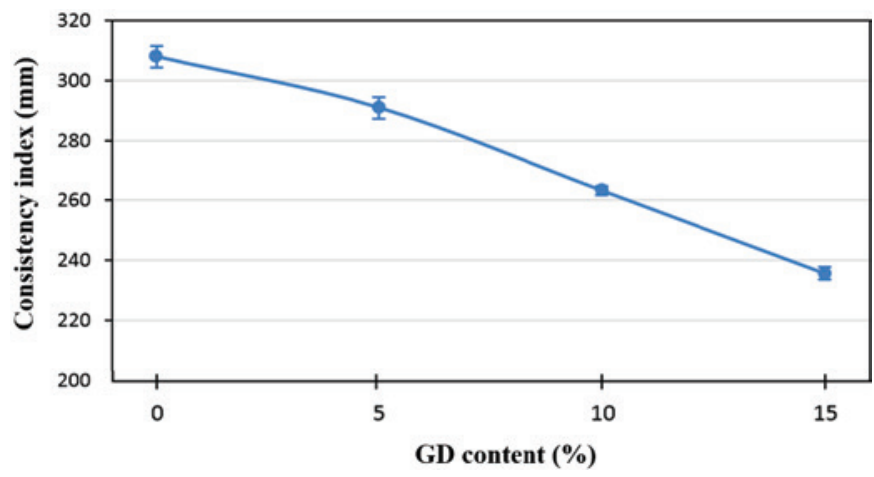

Figure 7

Consistency index (spread on flow table) of the cementitious matrices as a function of the GD content added

In order to carry out the test, pastes were prepared until the "normal consistency" recommended by the standard was reached and then the grinding dust was added in three different contents $(5 \%$, $10 \%$ and $15 \%$, relative to the cement weight).

\section{Results and discussions}

\subsection{Rheological characterization of cementitious matrix containing grinding dust}

Figure 7 shows the results obtained for the consistency indexes of the cementitious matrices in a flow table. A reduction of $17 \mathrm{~mm}$ (5.5\%), $44.7 \mathrm{~mm}(14.5 \%)$ and $72.33 \mathrm{~mm}(23.5 \%)$ in the consistency indexes in relation to the reference mortar was observed for the cementitious matrixes containing $5 \%, 10 \%$ and $15 \%$ of grinding dust, respectively. Despite the limitations of the technique (it is a monoponto evaluation), it is possible to observe that the addition of GD impacts on the workability of the mixture.

In Figure 8, the curves obtained in the squeeze-flow tests are presented. It can be observed that there is a reduction in plasticity as a function of the addition of grinding dust in the cementitious matrixes. The higher the GD content, the more rigid the mixture is, thus requiring higher loads to obtain the same deformation.

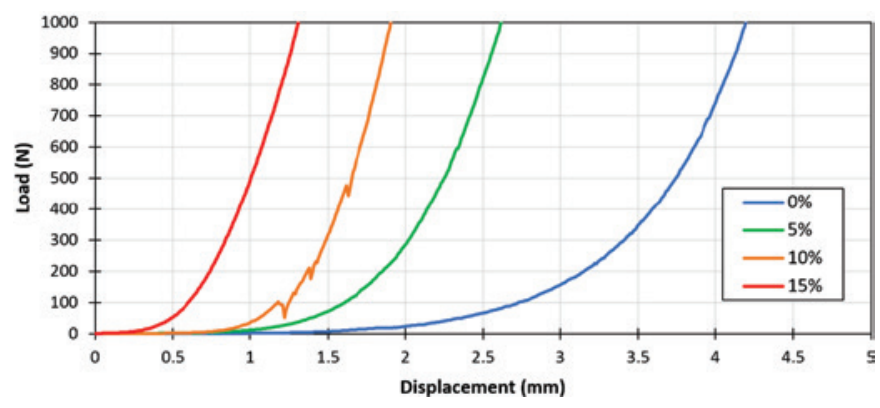

Figure 8

Rheological behavior of the cementitious matrixes with various ratios of GD added, evaluated by the squeeze-flow test 
Table 3

Yield stress and viscosity of the pastes with varying contents of grinding dust (GD)

\begin{tabular}{|c|c|c|c|c|c|c|c|c|}
\hline \multirow[t]{2}{*}{ Paste } & \multicolumn{2}{|c|}{$\begin{array}{c}\text { Yield stress } \\
(\mathrm{mN} \cdot \mathrm{m})-20 \mathrm{~min} \\
\end{array}$} & \multicolumn{2}{|c|}{$\begin{array}{c}\text { Yield stress } \\
(\mathrm{mN} \cdot \mathrm{m})-60 \mathrm{~min}\end{array}$} & \multicolumn{2}{|c|}{$\begin{array}{c}\text { Viscosity } \\
(\mathrm{mN} \cdot \mathrm{m} \cdot \mathrm{min})-20 \mathrm{~min}\end{array}$} & \multicolumn{2}{|c|}{$\begin{array}{c}\text { Viscosity } \\
(\mathrm{mN} \cdot \mathrm{m} \cdot \mathrm{min})-60 \mathrm{~min}\end{array}$} \\
\hline & Average & Deviation & Average & Deviation & Average & Deviation & Average & Deviation \\
\hline Reference & 1.86 & 0.239 & 3.39 & 0.271 & 0.054 & 0.007 & 0.100 & 0.017 \\
\hline $5 \%$ GD & 5.19 & 1.096 & 7.36 & 0.705 & 0.184 & 0.064 & 0.307 & 0.084 \\
\hline $10 \%$ GD & 8.53 & 0.115 & 11.30 & 1.386 & 0.205 & 0.037 & 0.366 & 0.035 \\
\hline $15 \%$ GD & 16.77 & 1.701 & 24.60 & 1.952 & 0.587 & 0.014 & 0.770 & 0.051 \\
\hline
\end{tabular}
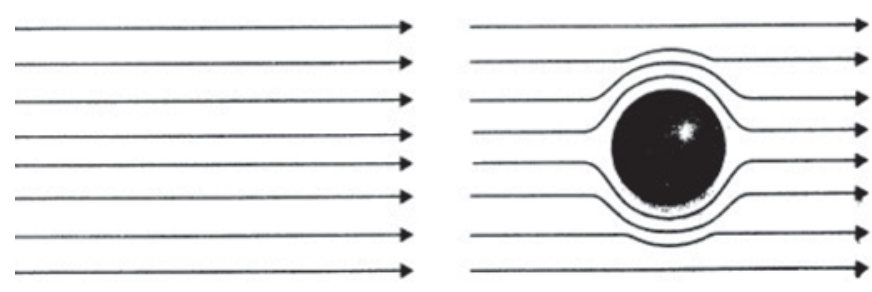

\section{Figure 9}

Effect of the presence of a spherical particle on

the flow lines of a fluid subjected to shear.

Fluid (a) free and (b) containing fine particles [43]

Table 3 shows the results of yield stress and viscosity of the mixtures with different contents of GD after 20 minutes and 60 minutes of the mixture, obtained by a rotational rheometry and from the application of the Herschel-Bulkley model. It can be observed that, for the evaluated times (20 min and $60 \mathrm{~min}$ ), the yield stress and the viscosity of the mixtures increase with the addition of GD.

The reduction in plasticity caused by the addition of GD, observed in the flow table, squeeze flow and rotational rheometry tests, is due to the higher content of fines present in the mixture. Fine par- ticles such as grinding dust in water have a natural tendency to agglomerate due to Van der Waals forces [37]. The presence of these agglomerates increases the viscosity and the yield stress of the mixture thus reducing its plasticity $[38,39]$.

Furthermore, the addition of fibers (such as mixed fiber present in $\mathrm{GD}$ ) in the cementitious matrix is responsible for causing a reduction in the fluidity of the mixture [40 - 42]. By introducing fibers into the cementitious matrix, fiber - fiber, fiber - wall of the mixing vessel and fiber - matrix interactions occur, which hinders the dispersion and homogenization process and reduces the fluidity of the system due to the formation of fiber and particle - fiber agglomerates [40].

In addition, the particles and the mixed fibers of the waste possibly act as a barrier to the flow and thereby disturb the flow lines. Because of this, the flow lines are curved rather than parallel sheets, thereby raising the viscosity of the mixture as shown in Figure 9 [43]. Another factor which explains the reduction in plasticity is the adsorption of a portion of the water from the mixture by the GD particles due to the fineness and high surface area of the waste, which impedes it from lubricating the solid particles [39]. The adsorption of a portion of the water, the angular shape of the GD particles (Figure 3), and the presence of fibers are responsible for increasing the

\section{Table 4}

Physical and mechanical properties of the cementitious matrices with varying grinding dust (GD) addition contents

\begin{tabular}{|c|c|c|c|c|}
\hline Property & Reference & $5 \%$ GD & $10 \%$ GD & $15 \%$ GD \\
\hline $\begin{array}{l}\text { Apparent density } \\
{\left[\mathrm{g} / \mathrm{cm}^{3}\right]}\end{array}$ & $1.97 \pm 0.01$ & $1.98 \pm 0.01$ & $1.96 \pm 0.01$ & $1.96 \pm 0.01$ \\
\hline $\begin{array}{c}\text { Apparent porosity } \\
{[\%]}\end{array}$ & $14.70 \pm 0.87$ & $13.29 \pm 0.44$ & $15.10 \pm 0.93$ & $15.31 \pm 0.46$ \\
\hline $\begin{array}{c}\text { Water absorption coefficient } \\
{\left[\mathrm{kg} / \mathrm{m}^{2} \cdot \mathrm{min}^{1 / 2}\right]}\end{array}$ & $0.13 \pm 0.01$ & $0.11 \pm 0.01$ & $0.13 \pm 0.01$ & $0.15 \pm 0.01$ \\
\hline $\begin{array}{l}\text { Height of capillary ascension } \\
{\left[\begin{array}{l}{[\mathrm{mm}]}\end{array}\right.}\end{array}$ & $3.47 \pm 0.16$ & $3.71 \pm 0.17$ & $4.75 \pm 0.24$ & $5.46 \pm 0.15$ \\
\hline $\begin{array}{c}\text { Tensile strength }-3 \text { days } \\
{[\mathrm{MPa}]}\end{array}$ & $5.59 \pm 0.23$ & $5.96 \pm 0.21$ & $4.90 \pm 0.33$ & $4.58 \pm 0.23$ \\
\hline $\begin{array}{c}\text { Tensile strength }-7 \text { days } \\
{[\mathrm{MPa}]}\end{array}$ & $8.57 \pm 0.29$ & $8.85 \pm 0.36$ & $7.14 \pm 0.21$ & $6.73 \pm 0.37$ \\
\hline $\begin{array}{c}\text { Tensile strength - } 28 \text { days } \\
{[\mathrm{MPa}]}\end{array}$ & $8.93 \pm 0.41$ & $9.40 \pm 0.58$ & $8.14 \pm 0.50$ & $7.41 \pm 0.10$ \\
\hline $\begin{array}{c}\text { Compressive strength }-3 \text { days } \\
{[\mathrm{MPa}]}\end{array}$ & $26.08 \pm 1.56$ & $27.56 \pm 2.06$ & $24.56 \pm 2.00$ & $24.53 \pm 1.61$ \\
\hline $\begin{array}{c}\text { Compressive strength - } 7 \text { days } \\
{[\mathrm{MPa}]}\end{array}$ & $31.41 \pm 1.09$ & $34.06 \pm 0.71$ & $32.00 \pm 1.47$ & $30.93 \pm 2.07$ \\
\hline $\begin{array}{c}\text { Compressive strength - } 28 \text { days } \\
{[\mathrm{MPa}]}\end{array}$ & $35.11 \pm 1.46$ & $36.50 \pm 1.77$ & $33.61 \pm 1.97$ & $32.69 \pm 2.07$ \\
\hline
\end{tabular}


internal friction of the particles during the flow and consequently reducing the plasticity of the mixture $[23,44]$.

\subsection{Influence of GD on the physical-mechanical properties of cementitious matrices}

Table 4 presents the physical properties of the cementitious matrices with different grinding dust contents at 28 days of curing, and the tensile and compressive strength at 3,7 and 28 days.

For the mixture with $5 \%$ of grinding dust, the fineness of the particle of the waste was possibly responsible for promoting an increase in the compactness of the mortar, resulting in a higher packing of particles, which increased the density of the matrix and decreased its porosity. For the mixtures with $10 \%$ and $15 \%$ of GD, the decrease in workability due to the addition of the waste generated difficulties in the molding of the specimens, which resulted in a higher porosity and, consequently, lower density of the cementitious matrices.

In relation to the capillary absorption coefficient, there was a $10.30 \%$ reduction in the value of the coefficient of the cementitious matrix with $5 \%$ of GD, when compared to the reference mortar. However, for the matrices with the addition of $10 \%$ and $15 \%$ of GD, increases of $1.73 \%$ and $16.27 \%$, respectively, are observed when compared to the reference mortar.

For the mixture with $5 \%$ of GD, pore filling by the particles of the waste reduced the capillary suction, resulting in a lower absorption coefficient. However, the same did not occur for the cementitious matrices with $10 \%$ and $15 \%$ of GD, probably due to the difficulty of densification during molding, which may have increased the porosity. This increase in the porosity must have included capillary pores or established a better connection between the existing pores.

According to MENG [45], pores larger than 0.1 micrometers $\left(10^{-7}\right.$ $\mathrm{m})$ and smaller than 1 millimeters $\left(10^{-3} \mathrm{~m}\right)$ are more relevant to the phenomenon of capillarity water rise. When we observe the particle size distribution of grinding dust, it can be seen that a significant portion of the particles are between $10 \mu \mathrm{m}$ and $100 \mu \mathrm{m}$, within the range relevant to the capillary absorption according to MENG [45]. With the addition of the grinding dust, some of the pores were probably obstructed or their diameter was reduced, which was reflected in the capillary rise height values that increased $6.91 \%$, $36.94 \%$ and $57.41 \%$ for the cementitious matrices with the addition of $5 \%, 10 \%$ and $15 \%$ of $\mathrm{GD}$, respectively, when compared to the reference mixture.

The reduction in the diameter and/or the increase in the quantity and interconnection between the capillary pores, due to the addition of GD, elevates the capillary pressures [46]. This results in a higher capillary rise height, as observed for the matrices with $10 \%$ and $15 \%$ of GD.

In relation to tensile and compressive strengths, the specimens of cementitious matrices with $5 \%$ of GD presented the best results, for all the ages evaluated. This can be attributed to the physical effect of the addition, which results in a higher packing of particles as confirmed in the apparent density and porosity tests. The higher compactness and density of the material are the result of filling the voids between the sand grains and between the hydration products of the cement by the particles of the waste (filler effect). In addition, the presence of mixed fibers (polyester, glass and metallic fibers) probably contributed to the increase in tensile strength observed in the cementitious matrix with $5 \%$ of GD. This can be explained by the ability of the fibers to interweave the cement hydration productions and dissipate energy, which hinders the propagation of microcracks and, consequently, increases the tensile strength [24].

However, for the matrices with $10 \%$ and $15 \%$ of GD there was a reduction in the mechanical strength, which is associated with the reduction in plasticity observed in the rheology tests. Due to the greater difficult in adequately dispersing the particles, agglomerates formed, which made it difficult to mold the specimens, increasing the porosity. According to CASTRO and PANDOLFELLI [47], the formation of agglomerates can alter the initially predicted particle size curve, consequently increasing the minimum effective diameter of the composition and decreasing the compactness, with the loss of the mechanical performance by the formation of the agglomerates, which are equivalent to empty particles and which give rise to pores in the microstructure.

\subsection{Analysis of cement pastes setting time}

In Figure 10 it can be seen that the addition of grinding dust to the CP V ARI cement retards the initial and final setting time of the cementitious matrix. With the addition of $5 \%, 10 \%$ and $15 \%$ of GD, increases of $36.57 \%, 68.98 \%$ and $101.39 \%$ respectively, were observed in the initial setting time and increases of $6.19 \%, 30.97 \%$ and $89.38 \%$, respectively, at the final setting time, measured by the Vicat needle.

The delay observed in the initial and final setting time can be attributed to the presence of zinc $(\mathrm{ZnO})$ and copper $(\mathrm{CuO})$ oxides and phenolic resins, which act as setting retarders, as discussed in the introduction.

The addition of grinding dust promoted an increase in the setting time of the cementitious matrix. This is due to the presence of zinc $(\mathrm{ZnO})$ and copper $(\mathrm{CuO})$ oxides in the GD. These oxides are possibly responsible for the precipitation of amorphous layers of $\mathrm{Zn}(\mathrm{OH})_{2}$ and $\mathrm{Cu}(\mathrm{OH})_{2}$, respectively, with low permeability and solubility, which block the hydration of $\mathrm{C}_{3} \mathrm{~S}$, thereby retarding the setting time of the cementitious matrix. The presence of phenolic

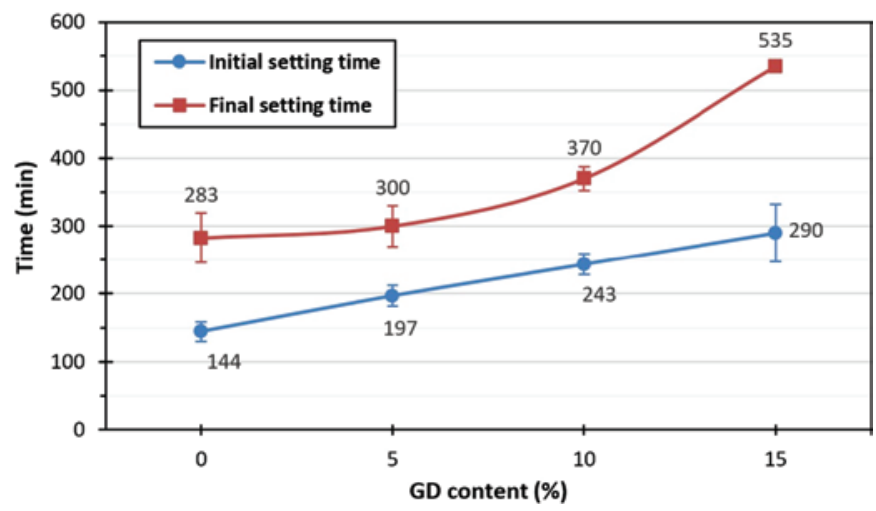

Figure 10

Variation of setting time of cement pastes as a function of the added GD content, using CP V-ARI cement 
resins in GD also contributes to this delay as during the hydration they are adsorbed onto the cement particles and, thus, they hamper the transport of water and the diffusion of calcium ions.

As a result, the grinding dust acts as an efficient setting retarder and does not significantly influence the other properties of the cementitious matrix, when added up to $5 \%$, which is technically feasible.

\section{Conclusions}

From the obtained results, it can be concluded that:

- Grinding Dust is classified as non-hazardous non-inert waste (Class II-A)

- The addition of Grinding Dust promotes an increase in the initial and final setting time of the Portland cement, due to the presence of zinc $(\mathrm{ZnO})$ and copper $(\mathrm{CuO})$ oxides, in addition to the phenolic resins

- The addition of the grinding dust influences the rheology of the cementitious matrices, increasing their viscosity and yield stress, as the particles and fibers of the waste disturb the flow lines and promote greater rigidity in the spatial structure of particles

- The addition of up to $5 \%$ of grinding dust resulted in a decrease in porosity and an increase in the density of the cementitious matrices studied due to the filling of pores (filler effect). However, due to the loss of plasticity and the consequent difficulty of molding, resulting from a lower water/dry materials ratio, the mixtures with $10 \%$ and $15 \%$ of GD had higher porosities and lower densities.

- There was a decrease in the capillary absorption coefficient with the addition of $5 \%$ of the waste, a behavior that is explained by the obstruction of the pores by the particles of GD

- The addition of GD at $5 \%$ contributed to the increase in the tensile and compressive strengths due to higher packaging of particles as the grinding dust fills the voids in the matrix in the hardened state, and due to the presence of mixed fibers that interweave the hydration products and dissipate energy, this hampers the spread of microcracks

- The decrease in tensile and compressive strengths found for the specimens with $10 \%$ and $15 \%$ GD when compared to the specimens with $5 \%$ GD may be due to the formation of particle agglomerates of the GD in the matrix, which can be compensated for by the use of dispersants.

- It is noted that the grinding dust is an effective setting retarder for cementitious matrices. However, studies are needed to improve the dispersion of the material in the cementitious matrix. The formation of agglomerates with higher levels of GD addition negatively impacted the physical and mechanical properties of the matrix.

\section{Acknowledgments}

The authors are grateful to the Coordination of Improvement of Higher Education Personnel (CAPES), the Civil engineering Postgraduate Program of the Federal University of Bahia (PPEC/UFBA), the Technological Center for Mortar (CETA) and ZF Sachs do Brasil Ltda.

\section{References}

[1] DEMAJOROVIC, J. A evolução dos modelos de gestão de resíduos sólidos e seus instrumentos. Cadernos FUNDAP,
1996. Disponível em: <http://web-resol.org/textos/demajorovic.pdf>. Acesso em: 13 jan. 2016.

[2] RIBEIRO, D.V. Influência da adição do pó de retífica em uma matriz de cimento de fosfato de magnésio. 2006. 128 p. Dissertação (Mestrado em Engenharia de Materiais) - Departamento de Ciência e Engenharia de Materiais, Centro de Ciências Exatas e de Tecnologia. Universidade Federal de São Carlos, São Carlos, 2006.

[3] THOMPSON, J.; ANTHONY, H. The Health Effects of Waste Incinerators. 4th Report of the British Society for Ecological Medicine. Second Edition, 2008.

[4] RIBEIRO, D.V.; MORELLI, M.R. Performance analysis of magnesium phosphate cement mortar containing grinding dust. Materials Research, v.12, p. 51-56, 2009.

[5] RIBEIRO, D.V.; MORELLI, M.R. Influence of the addition of grinding dust to a magnesium phosphate cement matrix. Construction and Building Materials, v.23, p. 3094-3102, 2009.

[6] RIBEIRO, D.V.; AGNELLI, J.A.M.; MORELLI, M.R. Study of mechanical properties and durability of magnesium phosphate cement matrix containing grinding dust. Materials Research, v.16, p. 1113-1121, 2013.

[7] ARLIGUIE G.; GRANDET J. Etude de l'effet retardateur du zinc sur l'hydratation de la patê de ciment Portland. Cement and Concrete Research, v.12, p. 79-86, 1982.

[8] HAMILTON, I.W.; SAMMES, N.M. Encapsulation of steel foundry bag house dusts in cement mortar. Cement and Concrete Research, v.29, n.1, p. 55-61, 1999.

[9] OLMO, I.F.; CHACON, E.; IRABIEN, A. Influence of lead, zinc, iron (III) and chromium (III) oxides on the setting time and strength development of Portland cement. Cement and Concrete Research, v.31, n.8, p. 1213-1219, 2001.

[10] LI, X. D.; ZHANG, Y. M.; POON, C. S.; LO, I. M. C. Study of zinc in cementitious material stabilized/solidified wastes by sequential chemical extraction and microstructural analysis. Chemical Speciation and Bioavailability, v. 13, p 1-7, 2001.

[11] YOUSUF, M.; MOLLAH, A.; VEMPATI, R.K.; LIN, T.C.; COCKE, D.L. The interfacial chemistry of solidification/stabilization of metals in cement and pozzolanic material systems. Waste Management, v.15, p. 137-148, 1995.

[12] ASAVAPISIT, S.; FOWLER, G.; CHEESEMAN, C.R. Solution chemistry during cement hydration in the presence of metal hydroxide wastes. Cement and Concrete Research, v.27, p. 1249-1260, 1997

[13] STEPHAN, D.; MALEKI, H.; KNOFEL, D.; EBER, B.; HARDTL, R. Influence of $\mathrm{Cr}, \mathrm{Ni}$, and $\mathrm{Zn}$ on the properties of pure clinker phases part I. C3S. Cement and Concrete Research, v.29, p. 545-552, 1999.

[14] TREZZA, M.A. Hydration study of ordinary Portland cement in the presence of zinc ions. Materials Research, v.10, p. 331-334, 2007.

[15] WEEKS, C.; HAND, R.J.; SHARP, J.H. Retardation of cement hydration caused by heavy metals present in ISF slag used as aggregate. Cement and Concrete Composities, v.30, p. 970-978, 2008.

[16] ATAIE, F. F.; JUENGER, M. C. G.; TAYLOR-LANGE, S. C.; RIDING, K. A. Comparison of the retarding mechanisms of zinc oxide and sucrose on cement hydration and interactions 
with supplementary cementitious materials. Cement and Concrete Research, v. 72, p 128-136, 2015.

[17] TASHIRO, C.; TAKAHASHI, H.; KANAYA, M.; HIRAKIDA, I.; YOSHIDA, R. Hardening Property of Cement Mortar Adding Heavy Metal Compound and Solubility of Heavy Metal from Hardened Mortar. Cement and Concrete Research, v. 7, p. 283-290, 1977.

[18] TASHIRO, C.; TATIBANA, S. Bond strength between C3S paste and iron, copper or zinc wire and microstructure of interface. Cement and Concrete Research, v. 13, p. 377-382, 1983.

[19] WILDING, C. R.; WALTER, A.; DOUBLE, D. D. A Classification of Inorganic and Organic Admixtures by Conduction Calorimetry. Cement and Concrete Research, v. 14, p. 185194, 1984.

[20] KAKALI, G.; TSIVILIS, S.; TSIALTAS, A. Hydration of Ordinary Portland Cements Made from Raw Mix Containing Transition Element Oxides. Cement and Concrete Research, v. 28 , p. 335-340, 1998.

[21] DOUBLE, D. D. New developments in understanding the chemistry of cement hydration. Philosophical Transactions of the Royal Society A, v. 310, p. 53-66, 1983.

[22] NELSON, E.B.; BARET, J; MICHAUX, M. Cement Additives and Mechanisms of Action. Developments in Petroleum Science, v.28, p. 3-1-3-37, 1990.

[23] SIMÕES, T.; COSTA, H.; DIAS-DA-COSTA, D.; JÚLIO, E. Influence of type and dosage of micro-fibres on the physical properties of fibre reinforced mortar matrixes. Construction and Building Materials, v. 187, p. 1277-1285, 2018.

[24] SIVAKUMAR, A.; SANTHANAM, M. Mechanical properties of high strength concrete reinforced with metallic and non-metallic fibres. Cement and Concrete Composites, v. 29, p. 603-608, 2007.

[25] ASSOCIAÇÃO BRASILEIRA DE NORMAS TÉCNICAS. Procedimento para obtenção de extrato lixiviado de resíduos sólido. - NBR 10005, Rio de Janeiro, 2004.

[26] ASSOCIAÇÃO BRASILEIRA DE NORMAS TÉCNICAS. Procedimento para obtenção de extrato solubilizado de resíduos sólidos. - NBR 10006, Rio de Janeiro, 2004.

[27] ASSOCIAÇÃO BRASILEIRA DE NORMAS TÉCNICAS. Resíduos sólidos - Classificação. - NBR 10004, Rio de Janeiro, 2004

[28] ASSOCIAÇÃO BRASILEIRA DE NORMAS TÉCNICAS. Argamassa para assentamento e revestimento de paredes e tetos - Preparo da mistura e determinação do índice de consistência. - NBR 13276, Rio de Janeiro, 2005.

[29] ASSOCIAÇÃO BRASILEIRA DE NORMAS TÉCNICAS. Argamassa de assasentamento e revestimento de paredes e tetos - Caracterização reológica pelo método squeeze-flow. - NBR 15839, Rio de Janeiro, 2010.

[30] BETIOLI, A.M.; JOHN, V.M.; GLEIZE, P.J.P.; PILEGGI, R.G. Caracterização reológica de pasta cimentícia: associação de técnicas complementares. Ambiente Construído, v. 9, p. 37-48, 2009.

[31] VIKAN, H.; JACOBSEN, S. Influence of rheology on the pumpability of mortar. In: SINTEF Building and Infrastructure. COIN Project report 21, 2010;

[32] LIU, Z.; HONG, J.; LIU, J. Rheological Behavior of Fresh Cement Asphalt Mortar. Proceedings of the Second International Conference on Sustainable Construction Materials:
Design, Performance, and Application. Sustainable Construction Materials. Wuhan, China, 2012;

[33] ANDRADE NETO, J. S; SILVA, V. S. Influência da sequência de mistura nas propriedades de argamassas industrializadas. In: anais eletrônicos do XII Simpósio Brasileiro de Tecnologia das Argamassas. São Paulo, 2017.

[34] ASSOCIAÇÃO BRASILEIRA DE NORMAS TÉCNICAS. Argamassa para assentamento e revestimento de paredes e tetos - Determinação da resistência à tração na flexão e à compressão. - NBR 13279, Rio de Janeiro, 2005.

[35] ASSOCIAÇÃO BRASILEIRA DE NORMAS TÉCNICAS. Argamassa e concreto endurecidos - Determinação da absorção de água por capilaridade. - NBR 9779, Rio de Janeiro, 2012.

[36] ASSOCIAÇÃO BRASILEIRA DE NORMAS TÉCNICAS. Cimento Portland - Determinação do tempo de pega. - NBR NM 65, Rio de Janeiro, 2003.

[37] PILEGGI, R. G., STUDART, A. R.; GALLO, J.; PANDOLFELLI, V. C. How Mixing Affects the Rheology of Refractory Castables - Part II. American Ceramic Society Bulletin, v. 80, p 27-31, 2001.

[38] YANG, M.; JENNINGS, H. M. Influences of Mixing Methods on the Microstructure and Rheological Behavior of Cement Paste. Advanced Cement Based Materials, v.2, p 70-78, 1995.

[39] CASTRO, A. L.; LIBORIO, J. B. L.; PANDOLFELLI, V. C. Reologia de concretos de alto desempenho aplicados na construção civil - Revisão. Cerâmica, v.57, p 63-75, 2011.

[40] FRANÇA, M. S.; CARDOSO, F. A.; PILEGGI, R. G. Influence of the addition sequence of PVA-fibers and water on mixing and rheological behavior of mortars. Revista IBRACON de Estruturas e Materiais, v. 9, no. 2, p. 226 - 243, 2016.

[41] CAO, Q.; CHENG, Y.; CAO, M.; GAO, Q. Workability, strength and shrinkage of fiber reinforced expansive selfconsolidating concrete. Construction and Building Materials, v. 131, p. 178-185, 2017.

[42] AKCAY, B.; TASDEMIR, M. A. Mechanical behavior and fibre dispersion of hybrid steel fibre reinforced self-compacting concrete. Construction and Building Materials, v. 28, p. 287-293, 2012.

[43] OLIVEIRA, R.I.; STUDART, A.R.; PILEGGI, R.G.; PANDOLFELLI, V.C. Dispersão e Empacotamento de Partículas. Princípios e aplicações em processamento cerâmico. São Paulo: Ed. Fazendo Arte Editorial, 2000, 195 p.

[44] RIBEIRO, D. V.; SILVA, A. S., LABRINCHA, J. A.; MORELLI, M. R. Rheological properties and hydration behavior of Portland cement mortars containing calcined red mud. Canadian Journal of Civil Engineering, v. 40, p 557-566, 2013

[45] MENG, B. Calculation of moisture transport coefficients on the basis of relevant pore structure parameters. Materials and Structure, v.27, p. 125-134, 1994.

[46] RIBEIRO, D. V. Estrutura dos poros e mecanismos de transporte no concreto. In: RIBEIRO, D. V. Corrosão em Estruturas de Concreto Armado: Teoria, Controle e Métodos de Análise. $1^{\mathrm{a}}$ edição, Elsevier, Rio de Janeiro, 2014, p. 75-85.

[47] CASTRO, A.L.; PANDOLFELLI, V.C. Revisão: conceitos de dispersão e empacotamento de partículas para a produção de concretos especiais aplicados na construção civil. Cerâmica, v.55, p. 18-32, 2009. 


\section{APPENDIX}

Table 5, which presents the ANOVA results, validates the information presented throughout this paper, in related to the statistical analyzes, and was added to assist the reviewers in the evaluation process, not being part of the paper

Table 5

ANOVA of the results evaluating the influence of grinding dust addition on the properties of the cementitious matrix

\begin{tabular}{|c|c|c|c|c|c|c|c|}
\hline Property & $S Q$ & GL & $M Q$ & $\mathbf{F}$ & P value & $F_{c}$ & $\begin{array}{l}\text { Significant } \\
\text { effect }\end{array}$ \\
\hline $\begin{array}{l}\text { Initial setting } \\
\text { time }\end{array}$ & 23330.67 & 3 & 7776.89 & 9.70 & 0.0048 & 4.07 & Yes \\
\hline $\begin{array}{l}\text { Final setting } \\
\text { time }\end{array}$ & 82292.25 & 3 & 27430.75 & 19.71 & 0.0004 & 4.07 & Yes \\
\hline $\begin{array}{l}\text { Consistency } \\
\text { index }\end{array}$ & 9081.67 & 3 & 3027.22 & 370.68 & 0.0000 & 4.07 & Yes \\
\hline $\begin{array}{l}\text { Yield stress } \\
\text { (20min) }\end{array}$ & 368.04 & 3 & 122.69 & 117.83 & 0.0000 & 4.07 & Yes \\
\hline $\begin{array}{l}\text { Yield stress } \\
\text { (60min) }\end{array}$ & 764.60 & 3 & 254.87 & 161.82 & 0.0000 & 4.07 & Yes \\
\hline $\begin{array}{l}\text { Viscosity } \\
\text { (20min) }\end{array}$ & 0.05 & 2 & 0.02 & 10.92 & 0.0150 & 5.79 & Yes \\
\hline $\begin{array}{l}\text { Viscosity } \\
\text { (60min) }\end{array}$ & 0.69 & 3 & 0.23 & 76.00 & 0.0000 & 4.07 & Yes \\
\hline $\begin{array}{l}\text { Apparent } \\
\text { Density }\end{array}$ & 0.00038 & 3 & 0.00013 & 5.03 & 0.0222 & 3.71 & Yes \\
\hline $\begin{array}{l}\text { Apparent } \\
\text { Porosity }\end{array}$ & 12.39 & 3 & 4.129 & 8.01 & 0.0020 & 3.29 & Yes \\
\hline $\begin{array}{c}\text { Water } \\
\text { absorption } \\
\text { coefficient }\end{array}$ & 0.01 & 3 & 0.01 & 7.57 & 0.0262 & 5.41 & Yes \\
\hline $\begin{array}{l}\text { Height of } \\
\text { capillary } \\
\text { ascension }\end{array}$ & 37.42 & 3 & 12.47 & 395.74 & 0.0000 & 2.79 & Yes \\
\hline $\begin{array}{l}\text { Tensile } \\
\text { strength - } \\
3 \text { days }\end{array}$ & 4.80 & 3 & 1.60 & 24.74 & 0.0000 & 3.49 & Yes \\
\hline $\begin{array}{l}\text { Tensile } \\
\text { strength - } \\
7 \text { days }\end{array}$ & 12.96 & 3 & 4.32 & 19.78 & 0.0000 & 3.41 & Yes \\
\hline $\begin{array}{l}\text { Tensile } \\
\text { strength - } \\
28 \text { days }\end{array}$ & 8.32 & 3 & 2.77 & 13.31 & 0.0003 & 3.41 & Yes \\
\hline $\begin{array}{l}\text { Compressive } \\
\text { strength - } \\
3 \text { days }\end{array}$ & 67.44 & 3 & 22.48 & 7.12 & 0.0005 & 2.81 & Yes \\
\hline $\begin{array}{l}\text { Compressive } \\
\text { strength - } \\
7 \text { days }\end{array}$ & 37.72 & 3 & 12.57 & 11.40 & 0.0002 & 3.13 & Yes \\
\hline $\begin{array}{l}\text { Compressive } \\
\text { strength - } \\
28 \text { days }\end{array}$ & 65.67 & 3 & 21.89 & 6.28 & 0.0027 & 3.01 & Yes \\
\hline
\end{tabular}

Note: $\mathrm{SQ}$ - Square sum; $\mathrm{GL}-$ Degrees of freedom; $\mathrm{MQ}$
significant. considering the $95 \%$ confidence interval. 